UDC 616.5

DOI: $10.15587 / 2519-4798.2017 .93603$

\title{
URBACH-WEITHE DISEASE (LIPOID PROTINOSIS): A CASE REPORT
}

\author{
(C) Mohammed Al Kaltham, Shayma Al Eid, Sadan Al Harbi, Ranyah Al Mazyad, Noura Al Hamad
}

Ліпоїдний протеїноз - ие рідкісний аутосомно- рецесивний розлад. 41 річний чоловік Сауді мав ураження шкіри, слизової оболонки рота та інші різноманітні прояви, перш за все, хрипоту голосу. Біопсія виявила відкладення гіаліну. Метою дослідження було описати досі не схарактеризовану хворобу арабського населення, ліпоїднй протеїноз

Ключові слова: ліпоїдний протеїноз, хворобливі відкладення, аутосомно-рецесивний

\section{Introduction}

Lipoid proteinosis (Urbach-Wiethe disease or Hyalinosis cutis et mucosae) is considered as a rare disorder, inherited as autosomal recessive pattern [1]. Lipoid proteinosis is caused by progressive hyaline material deposition in the skin, mucous membrane and different body organs [2]. Patients usually present with different clinical manifestations, classically appear in infants as a hoarse cry which results from laryngeal infiltration [3]. The objective of the present work is to report a large uncharacterized disease in Arab population such as lipoid proteinosis in middle adulthood male, who present with classical manifestations of the diseases with scrotal and genital ulceration.

\section{Aim}

To report a large uncharacterized disease in Arab population such as lipoid proteinosis in middle adulthood male.

\section{Case report}

A 41 year-old Saudi male, born to consanguineous parents. He started to follow up in Dermatology clinic eight years back when he presented with progressive skin and oral mucosal lesions. The skin lesions were distributed on face, extremities and groin. Since that time patient was on symptomatic treatment such as emollients and antihistamine. The patient had previous history of intertrigo on axilla and groin, he also was admitted as a case of left knee cellulitis.

The patient has history of frequent hospital visits. He follows up with ENT clinic due to hoarseness of voice which started in early childhood. He also had restricted tongue movement with speech impairment. Patient presented once to emergency department with respiratory obstruction, he was managed by tracheostomy tube insertion. Flexible fiberoptic nasopharyngoscopy was done, and showed nasoropharyngeal deposits with clear glottis and normal mobile vocal cord. He is also known to have gastroesophageal refluxe disease. Patient has a positive history of multiple attacks of seizures, he had computer tomography scan of brain with contrast, no abnormalities were noticed, but he follows up in Neurology clinic as a case of epilepsy. No history of visual disturbances, photosensitivity and family history was irrelevant.

On examination thickened hyperpigmented scaly plaques were distributed on, extremities and groin (Fig. 1, 2). Multiple atrophic depressed scars were found on forehead and cheeks.

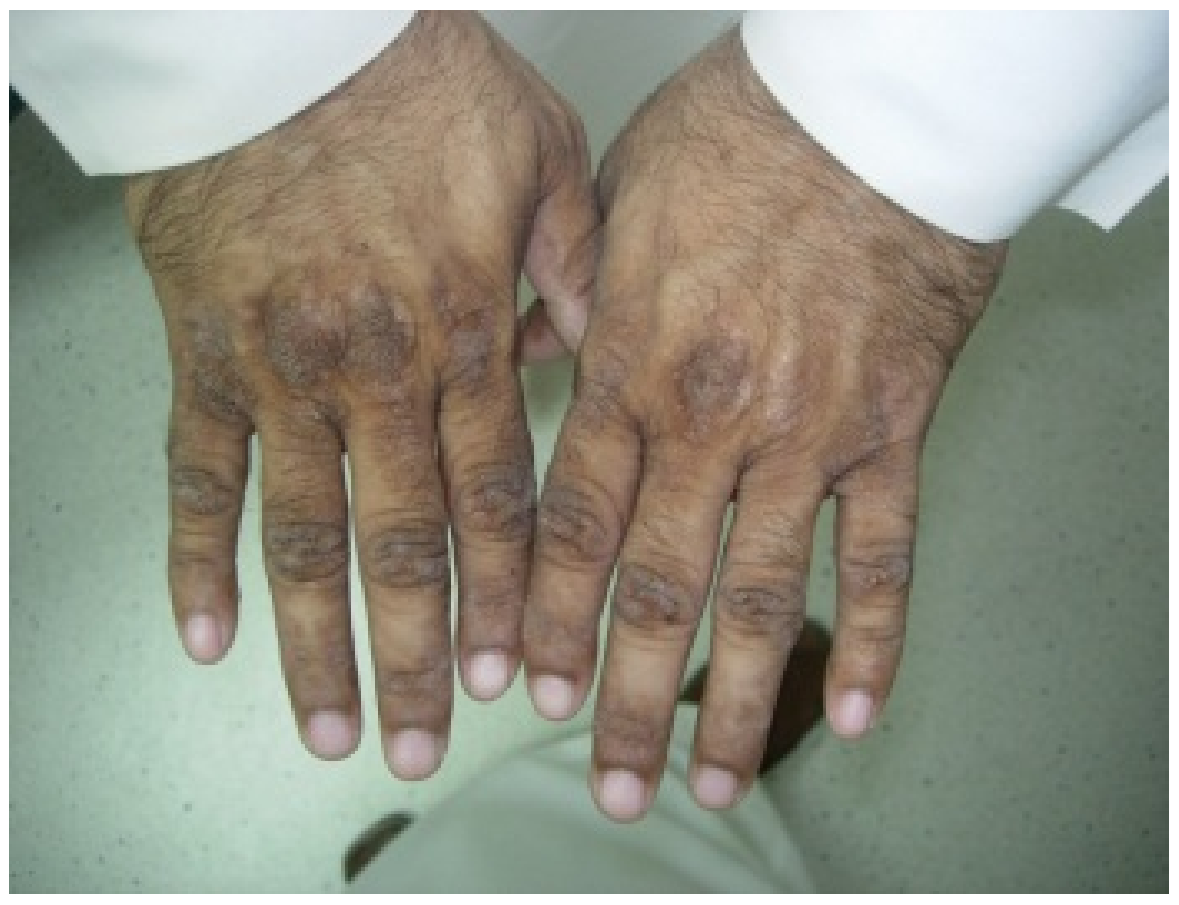

Fig. 1. Hyperkeratotic hyperpigmented scaly verrucous plaques on the dorsum of the hands

Beaded papules on thickened margins of the eyelids was also noticed. On oral cavity a thickened lingual mucosa with nodular infiltration was appreciated (Fig. 3).

Examination also revealed scrotal with genital ulcers. Systemic examination revealed no abnormalities.

Routine investigations were normal. Biopsy from oral mucosa was taken and revealed epithelial hyperplasia and hyaline like deposition in the subepithelial tissue with hyaline mantles around the blood vessels (Fig. 4). 


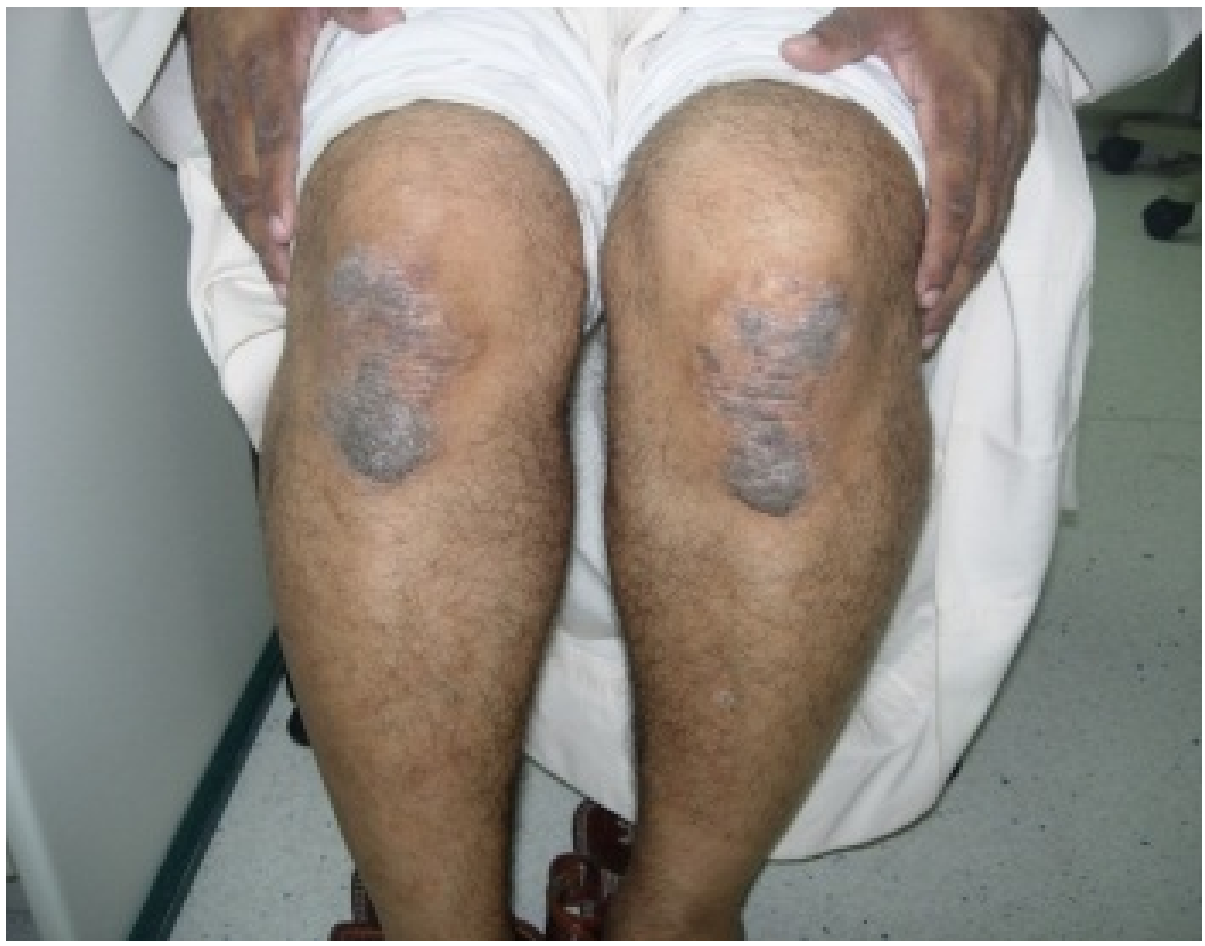

Fig. 2. Hyperkeratotic hyperpigmented scaly verrucous plaques on the knees

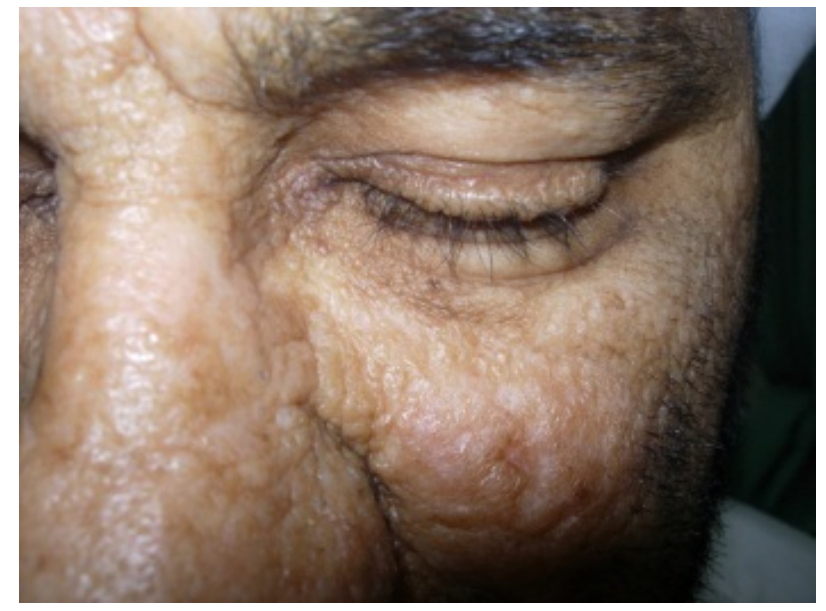

Fig. 3. A row of beaded papules on the margin of the upper eyelid

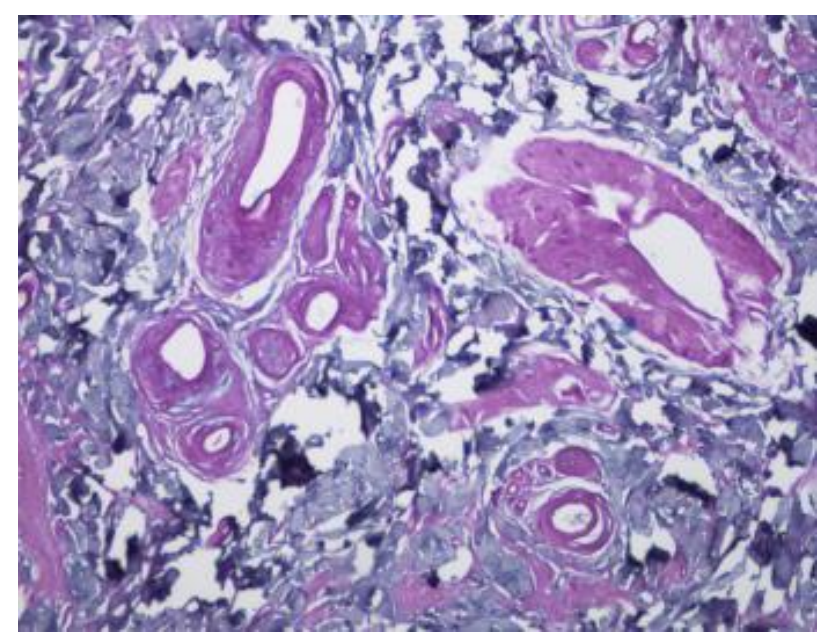

Fig. 4. Histopathology shows epithelial hyperplasia and hyaline like deposition in the subepithelial tissue with hyaline mantles around the blood vessels $(\mathrm{H} \& \mathrm{E}, \times 40)$

\section{Discussion}

Lipoid proteinosis (Urbach-Wiethe disease or Hyalinosis cutis et mucosae) which is considered as a rare disorder, inherited as autosomal recessive pattern. The diagnosis depends on the clinical manifestations of the disease and confirmed by biopsy $[2,3]$.

In 2002, a pathogenic mutation in extracellular matrix protein 1 gene (ECM1) on chromosome 1q21 was found to cause lipoid proteinosis [4]. ECM1 gene is responsible of controlling epidermal differentiation [5]. It works as a "biological glue" in the dermis, by regulating basement membrane and interstitial collagen fibril macro-assembly and growth factor binding. ECM1 mutation alters the dermal homeostasis, that will lead to a hyaline material deposition in skin and other sites like oral cavity, larynx, central nervous system, and others $[6,7]$.

Usually the hoarse voice is the first thing that patients can present with as in our patient, and it may either develop in infancy or in early childhood [3].

Skin lesions usually follow the hoarseness and develop within first few years of life. The first skin lesions are often blisters in early childhood [2]. Many patients presents with generalized skin thickening on the face, trunk, flexures, extremities and groin [3]. Some patients presents with acneform scarring particularly in face and extremities $[2,3]$. These scarring may follow trauma or occur spontaneously [2]. Our patient developed a waxy papules and atrophic scars mainly on face with plaques distributed in the body.

Beaded papules around the eyelid margins (moniliform blepharosis) are typically found in our patient which is a pathognomonic sign of lipoid proteinosis, similar lesions are also found in oral cavity $[1,3]$. The lips, tongue, soft palate, tonsils and pharynx are usually involved. Limited tongue movements and speech difficulties as noticed 
in our case are caused by hyaline deposition in the sublingual frenulum and tongue. Many of patients suffer of xerostomia, dental abnormalities and dysphagia as a result of oral cavity infiltration [2]. Infiltration can also involve pharynx and larynx leading to respiratory distress ending up with tracheostomy tube insertion as in our patient [2].

Our patient had multiple attacks of seizures, which is common in lipoid proteinosis. Other mental retardation, and neuropsychiatric illnesses can also seen in the lipoid proteinosis [3].

Other extracutaneous features as ocular manifestations may include dry eyes, open angle glaucoma, drusen in the macula, retinitis pigmentosa, uveitis and subluxation of the lens has been reported along with lipoid proteinosis, which were not founded in our case [8].

In CT scan study, we could not find any calcification of the temporal lobe or hioppocampi, which usually appears as bean-shaped opacities and considered to be pathognomonic of the disease [3].

Histopathology of lipoid proteinosis shows thickening at the dermoepidermal junction caused by deposition of hyaline material at the level of basement membrane [7]. These histopathological characteristics described above matches the histology of our case [6].

There is no definitive treatment till now. Dimethyl sulfoxide, oral retinoids, and dermabrasion have been shown to improves skin lesions. Surgical management such as microlaryngeal surgery of the vocal cords using $\mathrm{CO}_{2}$ laser to reduce their thickness and hoarseness [1]. Acitretin in a couple of case reports shows a significant improvement in hoarseness of voice, while a very minimal to no improvement in cutaneous lesion $[9,10]$. Our patient is on symptomatic treatment as emollients and antihistamine but still he didn't show significant improvement. Potassium permanganate, bactroban and Augmentin was prescribed for the scrotal ulcer and healed completely after two weeks.

\section{Conclusion}

To sum it up, our patient is born to consanguineous parents which plays an important role of the disease presentation. In Saudi Arabia community where consanguineous marriages are very common, this can increase the incidence of such a disease in offspring, which should arise the need of spreading awareness in public. The wide list of presentations our patient came with, starting with early childhood hoarseness to the specific early skin lesions should help in early diagnosis of lipoid protienosis. Awareness among dermatologists about this entity is crucial for proper diagnosis. Life threatening conditions of lipoid protienosis most importantly acute airway obstruction and seizures should emphasize the need of early diagnosis and early referral to other specialty clinics to prevent such fatal complications.

\section{References}

1. Thaddanee, R. Lipoid proteinosis (Urbach-Wiethe disease) in two siblings [Text] / R. Thaddanee, A. Khilnani, P. Pandya, M. Chaturvedi // Indian Dermatology Online Journal. - 2014. - Vol. 5, Issue 6. - P. 95-97. doi: 10.4103/2229-5178.146168

2. Mittal, H. C. Lipoid Proteinosis [Text] / H. C. Mittal, S. Yadav, S. Malik, G. Singh // International Journal of Clinical Pediatric Dentistry. - 2016. - Vol. 9. - P. 149-151. doi: 10.5005/jp-journals-10005-1353

3. Rao, R. Lipoid proteinosis [Text] / R. Rao, S. Betkerur, C. Babu, V. Sudha // Journal of Oral and Maxillofacial Pathology. 2009. - Vol. 13, Issue 2. - P. 81-84. doi: 10.4103/0973-029x.57675

4. Chan, I. The molecular basis of lipoid proteinosis: mutations in extracellular matrix protein 1 [Text] / I. Chan, L. Liu, T. Hamada, G. Sethuraman, J. A. McGrath // Experimental Dermatology. - 2007. - Vol. 16, Issue 11. - P. 881-890. doi: 10.1111/j.16000625.2007.00608.x

5. Bakry, O. A. Two Egyptian cases of lipoid proteinosis successfully treated with acitretin [Text] / O. A. Bakry, R. M. Samaka, N. S. Houla, M. A. Basha // Journal of Dermatological Case Reports. - 2014. - Vol. 8, Issue 1. - P. 29-34. doi: 10.3315/jdcr.2014.1168

6. Sangwan, A. Urbach-Weithe disease (lipoid proteinosis): A classical presentation [Text] / A. Sangwan, S. Kaur, V. Jain, S. Dayal // Indian Dermatology Online Journal. - 2016. - Vol. 7, Issue 2. - P. 143-144. doi: 10.4103/2229-5178.178089

7. Giandomenico, S. Di. Lipoid Proteinosis: Case report and review of the literature [Text] / S. Di. Giandomenico, R. Masi, D. Cassandrini, M. El-Hachem, R. De Vito, C. Bruno, F. M. Santorelli // Acta Otorhinolaryngologica Italica. - 2006. - Vol. 26, Issue 3. - P. 162-167.

8. Devi, P. Lipoid proteinosis: A rare entity [Text] / P. Devi, M. Bipasha // Indian Journal of Ophthalmology. - 2015. - Vol. 63, Issue 8. - P. 680-681. doi: 10.4103/0301-4738.169791

9. Toosi, S. Treatment of lipoid proteinosis with acitretin: a case report [Text] / S. Toosi, A. Ehsani // Journal of the European Academy of Dermatology and Venereology. - 2009. - Vol. 23, Issue 4. - P. 482-483. doi: 10.1111/j.1468-3083.2008.02928.x

10. Gunduz, O. Acitretin Treatment for Lipoid Proteinosis [Text] / O. Gunduz, N. Sahiner, P. Atasoy, C. Senyucel // Case Reports in Dermatological Medicine. - 2012. - Vol. 2012. - P. 1-4. doi: 10.1155/2012/324506

Дата надходження рукопису 10.01.2017

Mohammed Al Kaltham, Department of Dermatology, Dammam Medical Tower, King Khaled Rd, Dammam, Saudi Arabia, 32245

Shayma Al Eid, Medical Intern, Collage of Medicine, Imam Abdulrahman Al Faisal University (University of Dammam), King Fahad Hospital of the University, PO Box 1982, Dammam, Saudi Arabia, 31441

E-mail: helpdesk@uod.edu.sa 
Sadan Al Harbi, Medical Intern, Collage of Medicine, Imam Abdulrahman Al Faisal University (University of Dammam), King Fahad Hospital of the University, PO Box 1982, Dammam, Saudi Arabia, 31441

E-mail: helpdesk@uod.edu.sa

Ranyah Al Mazyad, Medical Intern, Collage of Medicine, Imam Abdulrahman Al Faisal University (University of Dammam), King Fahad Hospital of the University, PO Box 1982, Dammam, Saudi Arabia, 31441

E-mail: helpdesk@uod.edu.sa

Noura Al Hamad, Medical Intern, Collage of Medicine, Imam Abdulrahman Al Faisal University (University of Dammam), King Fahad Hospital of the University, PO Box 1982, Dammam, Saudi Arabia, 31441

E-mail: helpdesk@uod.edu.sa

УДК 617.581:617.5-001] (045)

DOI: $10.15587 / 2519-4798.2017 .93292$

\title{
АНАЛІЗ СУЧАСНИХ МЕТОДІВ ДІАГНОСТИКИ У ПОСТРАЖДАЛИХ 3 НЕСТАБІЛЬНИМИ ПОШКОДЖЕННЯМИ ТАЗА І ТАЗОВИХ ОРГАНІВ ПРИ ПОЛІТРАВМІ В ГОСТРОМУ ПЕРІОДІ ТРАВМАТИЧНОЇ ХВОРОБИ
}

\author{
(C) М. Л. Анкін, В. В. Бурлука, С. О. Король \\ Метою дослідження було удосконалення діагностичної програми у постраждалих з нестабільними \\ пошкодженнями таза і тазових органів при політравмі на основі оцінки тяжкості травми з метою \\ вибору оптимальної хірургічної тактики лікування в гострому періоді травматичної хвороби. Одер- \\ жані результати дозволили розробити схему променевої діагностики нестабільного тазового кільия, \\ а також скоротити терміни виявлення пошкоджень тазових органів у пацієнтів при нестабільному $i$ \\ критичному станах
}

Ключові слова: нестабільний таз, політравма, тазові органи, методи діагностики, гострий період травматичної хвороби

\section{1. Вступ}

Ступінь та характер пошкодження тазового кільця розцінюється як показник тяжкості травми [1-5]. Поняття стабільності таза визначає подальшу тактику, а використання класифікацій пошкоджень за M. Tile - AO/ASIF i Letournel - AO/ASIF допомагає вибрати найбільш раціональний спосіб лікування i прогнозувати функціональні результати пошкоджень кісток тазу і переломів вертлюгової западини у конкретних постраждалих $[6,7]$.

Постраждалого 3 пошкодженням тазової ділянки при політравмі (ISS $\geq 17$ балів) необхідно розглядати як такого, який потенційно має приховану катастрофічну травму внутрішніх органів, магістральних судин і тому йому в найближчий час необхідно провести мультидисциплінарне обстеження $[8,9]$.

Близько 60 \% постраждалих з пошкодженнями тазової ділянки (ПТД) при політравмі мають поєднання нестабільних переломів кісток тазу і пошкоджень тазових органів [2, 10, 11].

При вкрай тяжкій травмі (біля 20 \% постраждалих, ISS $>40$ балів), багато клінічних симптомів неможливо визначити і тоді діагноз пошкоджень кісток таза та тазових органів встановлюється тільки на основі променевих (оглядова, багатопроекційна коса рентгенографія, ретроградна контрастна уретроцистографія, спіральна комп'ютерна томографія (СКТ)) та інструментальних методів дослідження (лапароцентез, діагностична мікролапаротомія).

Клінічні ознаки поєднаних пошкоджень таза та його органів різноманітні, їх вираженість нівелюється симптомами конкуруючого або домінуючого пошкодження, дією медикаментозних засобів, проте, детальний аналіз клінічних симптомів, результатів лабораторних та інструментальних досліджень дозволяє вчасно їх діагностувати. Об'єм і послідовність сучасних методів діагностики залежить в першу чергу від тяжкості травми, а також від оснащення стаціонару, куди доставляють постраждалого. Аналіз даних літератури $[10,12,13]$ свідчить про те, що клініко-діагностична програма у постраждалих 3 ПТД при тяжкій множинній та поєднаній травмі в гострому (1-3 доба) періоді травматичної хвороби (TX) повністю не визначена і потребує доопрацювання.

\section{2. Обгрунтованість дослідження}

При тяжких та вкрай тяжких ПТД в умовах операційної паралельно 3 протишоковими заходами виконують, як правило, наступні діагностичні обстеження: рентгенологічні та ендоскопічні дослідження, катетеризацію сечового міхура 3 проведенням рентгенконтрасної уретроцистографії за показаннями, торакопункцію, торакоцентез, лапароцентез, мікролапаротомію за показаннями [14-16]. 